\title{
Echocardiographic left ventricular hypertrophy in Chinese endurance athletes
}

\author{
Y. S. A. Lo MD, FRCP1, 2 and M. K. Chin PhD ${ }^{2}$ \\ ${ }^{1}$ Hong Kong Heart Centre \\ ${ }^{2}$ Jubilee Sports Centre, Hong Kong
}

\begin{abstract}
Most echocardiographic data on the athletic heart syndrome originate from the United States and Western Europe. There are no published data on echocardiographically documented left ventricular hypertrophy in Asian athletes. We investigated the echocardiographic changes which take place with endurance training by studying eight Hong Kong national cyclists. This study confirms that left ventricular hypertrophy and increased left ventricular end-diastolic dimensions are common findings in Chinese endurance athletes as in their Caucasian counterparts. Calculated left ventricular muscle mass exceeded the 95th percentile in seven of eight subjects.
\end{abstract}

Keywords: Echocardiography, left ventricular hypertrophy, athlete's heart

\section{Introduction}

Prolonged and consistent physical training in endurance athletes tends to result in an altered cardiac physiology. Such altered cardiac physiology is commonly referred to as the 'athletic heart syndrome', and presents itself in any of the following forms: cardiac murmurs, marked bradycardia, abnormal electrocardiogram, enlarged silhouette on chest $X$-ray, and left ventricular hypertrophy on echocardiography ${ }^{1}$. Most echocardiographic data on the athletic heart syndrome originate from the United States and Western Europe. To the best of the authors' knowledge, there has not been any published data on echocardiographically documented left ventricular hypertrophy in Asian athletes. We investigated the echocardiographic changes which take place with endurance training by studying the Hong Kong national cyclists.

\section{Methods}

Eight Hong Kong national cyclists of ethnic Chinese origin participated in the study before election to the Seoul Olympics in 1988. All subjects were asymptomatic, healthy individuals without any prior history

Address for correspondence: Dr Y.S. Archie Lo, Hong Kong Heart Centre, 40 Stubbs Road, Hong Kong

(C) 1990 Butterworth-Heinemann Ltd 0306-3674/90/040274-03 of heart disease who engaged in year-round intensive endurance training on a regular, almost daily basis. Each training session consisted of 2-3 hours of road-cycling, at an intensity between 70 and $85 \%$ $\mathrm{VO}_{2 \max }$.

\section{Physiologic and physical evaluations}

Anthropometric measurements included body weight, height, vital capacity and body fat content. Percentage body fat was estimated from measurements of skinfold-thickness with a Harpenden Skinfold Caliper at three different sites of the body surface $^{2}$. The subjects were also submitted to a direct, continuous, multistage, maximal oxygen uptake determination $\left(\mathrm{VO}_{2 \max }\right)$ performed on an electromagnetically braked bicycle ergometer equipped with toe clips (Lannooy, Lode's Instrument, Gronigen, Holland). Initial load was set at $150 \mathrm{~W}$ and work rate was increased by $25 \mathrm{~W}$ every minute, following a 3 minute $100 \mathrm{~W}$ warm up period, until exhaustion. Heart rate was calculated from the continuously monitored electrocardiogram. Oxygen uptake and $\mathrm{CO}_{2}$ output were measured by the open circuit method using a Gould 2900 Energy Expenditure Unit. The leveling-off criterion for heart rate and oxygen consumption was used to extablish $\mathrm{VO}_{2 \max }$ values.

\section{Echocardiographic evaluation}

Resting echocardiographic examination was performed using a Hewlett-Packard 77020 echocardiograph. All subjects were examined in the left lateral decubitus position and the usual parasternal and apical windows were used. Both M-mode and 2-D imaging were employed for measurements. Measurements of the left ventricular posterior free wall, septum, left ventricular end-diastolic dimension, left ventricular end-systolic dimension were in accordance with the recommendations of the American Society of Echocardiography ${ }^{3}$. Left ventricular mass was estimated using the Penn Convention". The American Society of Echocardiography standards for the normal population were used for comparison, and dimensions above the 95th percentile, adjusted for body surface area, were considered increased. 
Colour-Doppler flow-imaging was performed to exclude any significant valvular regurgitation or septal defects. Pulsed Doppler was performed in cases of left ventricular hypertrophy to determine if an outflow tract gradient was present.

\section{Results}

\section{Physiologic and physical characteristics}

Anthropometric and physiologic data for the subjects appear in Table $1 A$ and Table $1 B$. The mean value of $5.1 \pm 1.9 \%$ body fat of the Hong Kong national cyclists is similar to that for international elite cyclists ${ }^{5}$. The Hong Kong cyclists have the metabolic characteristics of high-calibre endurance-trained athletes. The mean value of $\mathrm{VO}_{2 \max }$ was $72 \mathrm{ml} . \mathrm{kg}^{-1} \mathrm{~min}^{-1}$ which is comparable to that of international elite cyclists reported in other studies $^{6-8}$. Cyclist 5 from the present study who had the highest $V^{2 \max }$ value of $77.4 \mathrm{ml} . \mathrm{kg}^{-1} \mathrm{~min}^{-1}$, finished 12th overall and first in Asia in the road race of the Seoul Olympics in 1988.

\section{Echocardiographic characteristics}

The results of echocardiographic measurements are listed in Table $1 A$ and $1 B$. There was no evidence for valvular pathology or atrial/ventricular septal defects in all subjects studied. Ventricular systolic function was normal in all subjects. No cases of left ventricular hypertrophy were associated with systolic anterior motion of the mitral valve, presence of an intraventri- cular gradient and/or turbulence of intraventricular blood flow. The mean septum to left ventricular posterior free wall ratio was 1.1 with a range from 1 to 1.33; two of eight subjects had ratios $>1.3$.

\section{Discussion}

Several echocardiographic studies have confirmed that endurance athletes usually possess cardiac dimensions which are larger than sedentary individuals $^{9,10}$. Such hypertrophy is a normal physiological response and should not be regarded as a pathological condition. Indeed, radiographic cardiomegaly is not uncommon in athletes and a cardiothoracic ratio often approaches or exceeds $0.5^{1}$. As in their Caucasian counterparts, this study confirms that left ventricular hypertrophy and increased left ventricular end-diastolic dimensions are also common findings in Chinese endurance athletes. Calculated left ventricular muscle mass exceeded the 95th percentile of standards used in seven of eight subjects.

This study also demonstrated a tendency for the septum to be relatively more hypertrophied than the left ventricular posterior free wall. In the available literature, the septum to left ventricular posterior free wall ratio is greater than 1.3 (asymmetric septal hypertrophy) in $40 \%$ of athletes studied ${ }^{1}$. A logical question to ask is whether some of the athletes with asymmetric septal hypertrophy may in fact have hypertrophic cardiomyopathy. However, other than septal hypertrophy, there was no evidence to

Table 1A. Physical and echocardiographic characteristics of individual cyclist

\begin{tabular}{|c|c|c|c|c|c|c|c|c|c|c|c|}
\hline Subject & $\begin{array}{c}\text { Age } \\
(y r)\end{array}$ & $\begin{array}{c}\text { Height } \\
\text { (cm) }\end{array}$ & $\begin{array}{c}\text { Weight } \\
(\mathbf{k g})\end{array}$ & $\begin{array}{l}B S A \\
\left(M^{2}\right)\end{array}$ & $\begin{array}{c}V O_{2 \max } \\
(\mathrm{ml} / \mathrm{kg} / \mathrm{min})\end{array}$ & $\begin{array}{c}\text { FVC } \\
\text { (litre) }\end{array}$ & $\begin{array}{l}\text { LVEDD } \\
(\mathrm{cm})\end{array}$ & $\begin{array}{l}\text { LVESD } \\
(\mathrm{cm})\end{array}$ & $\begin{array}{l}\text { SEP } \\
(\mathrm{cm})\end{array}$ & $\begin{array}{l}\text { LVPFW } \\
\text { (cm) }\end{array}$ & $\begin{array}{l}\text { LVM } \\
\text { (gm) }\end{array}$ \\
\hline $\begin{array}{l}1 \\
2 \\
3 \\
4 \\
5 \\
6 \\
7 \\
8\end{array}$ & $\begin{array}{l}30 \\
29 \\
23 \\
20 \\
24 \\
19 \\
24 \\
20\end{array}$ & $\begin{array}{l}178 \\
165 \\
176 \\
179 \\
176 \\
176 \\
168 \\
172\end{array}$ & $\begin{array}{l}61 \\
62 \\
64 \\
68 \\
67 \\
63 \\
59 \\
63\end{array}$ & $\begin{array}{l}1.63 \\
1.55 \\
1.65 \\
1.71 \\
1.67 \\
1.64 \\
1.54 \\
1.60\end{array}$ & $\begin{array}{l}75.5 \\
71.0 \\
70.6 \\
69.2 \\
77.4 \\
71.4 \\
68.9 \\
73.0\end{array}$ & $\begin{array}{l}4.74 \\
4.28 \\
4.45 \\
4.94 \\
4.28 \\
5.48 \\
4.24 \\
4.98\end{array}$ & $\begin{array}{l}5.5 \\
5.4 \\
5.4 \\
5.9 \\
5.4 \\
5.2 \\
5.0 \\
5.4\end{array}$ & $\begin{array}{l}3.4 \\
3.5 \\
3.3 \\
3.6 \\
3.2 \\
3.2 \\
3.3 \\
3.0\end{array}$ & $\begin{array}{l}1.2 \\
1.1 \\
1.0 \\
1.1 \\
0.9 \\
1.2 \\
1.2 \\
1.1\end{array}$ & $\begin{array}{l}0.9 \\
1.0 \\
1.0 \\
1.1 \\
0.9 \\
0.9 \\
1.2 \\
1.0\end{array}$ & $\begin{array}{l}269 \\
261 \\
244 \\
325 \\
210 \\
244 \\
277 \\
261\end{array}$ \\
\hline
\end{tabular}

Table 1B. Group statistics

\begin{tabular}{|c|c|c|c|c|c|c|c|c|c|c|c|}
\hline Subject & $\begin{array}{c}\text { Age } \\
(y r)\end{array}$ & $\begin{array}{c}\text { Height } \\
\text { (cm) }\end{array}$ & $\begin{array}{c}\text { Weight } \\
\text { (kg) }\end{array}$ & $\begin{array}{c}\text { Body Fat } \\
(\%)\end{array}$ & $\begin{array}{c}V O_{2 \max } \\
(\mathrm{ml} / \mathrm{kg} / \mathrm{min})\end{array}$ & $\begin{array}{l}\text { FVC } \\
\text { (litre) }\end{array}$ & $\begin{array}{l}\text { LVEDD } \\
\left(\mathrm{cm} / \mathrm{M}^{2}\right)\end{array}$ & $\begin{array}{l}\text { LVESD } \\
\left(\mathrm{cm} / \mathrm{M}^{2}\right)\end{array}$ & $\begin{array}{c}S E P \\
\left(c m / M^{2}\right)\end{array}$ & $\begin{array}{l}\text { LVPFW } \\
\left(\mathrm{cm} / \mathrm{M}^{2}\right)\end{array}$ & $\begin{array}{c}L V M \\
\left(g m / M^{2}\right)\end{array}$ \\
\hline $\begin{array}{l}\text { mean } \\
\text { Range } \\
\text { 95th }\end{array}$ & $\begin{array}{l}24 \pm 4 \\
19-30\end{array}$ & $\begin{array}{l}174 \pm 4 \\
165-179\end{array}$ & $\begin{array}{c}63 \pm 3 \\
59-68\end{array}$ & $\begin{array}{c}5.1 \\
3.8-9.8\end{array}$ & $\begin{array}{c}72 \pm 3 \\
69-77\end{array}$ & $\begin{array}{c}4.7 \pm 0.4 \\
4.2-5.5\end{array}$ & $\begin{array}{c}3.4 \pm 0.1 \\
3.2-3.5 \\
7 / 8\end{array}$ & $\begin{array}{c}2.1 \pm 0.1 \\
1.9-2.3 \\
1 / 8\end{array}$ & $\begin{array}{c}0.67 \pm 0.08 \\
0.54-0.78 \\
6 / 8\end{array}$ & $\begin{array}{c}0.62 \pm 0.07 \\
0.54-0.78 \\
2 / 8\end{array}$ & $\begin{array}{c}161 \pm 20 \\
126-190 \\
7 / 8\end{array}$ \\
\hline
\end{tabular}

95th percentile $=$ number of patients over the 95th percentile

FVC $=$ forced vital capacity

LVEDD = left ventricular end-diastolic dimension

LVESD = left ventricular end-systolic dimension

LVM = left ventricular mass estimated using the Penn Convention: LVM $=1.04\left[(S E P+\text { LVEDD + LVPFW })^{3}-13.6 \mathrm{~g}-\right.$ LVEDD $\left.^{3}\right]$

LVPFW = left ventricular posterior free wall

SEP $=$ septum 
corroborate the diagnosis of hypertrophic cardiomyopathy.

With the increasing awareness of the importance of and necessity for regular exercise in many Asian countries in the last decade, it is important that physicians be aware that ventricular hypertrophy is part and parcel of the athletic heart syndrome, and that otherwise healthy endurance-trained athletes should not be inappropriately labelled as having cardiac pathology.

\section{Acknowledgements}

The authors are sincerely grateful to the cyclists who participated in the study. They also express their appreciation to Raymond So, Winnie Lau, Jessie Cheng and Judy Cheng for their technical and clerical support in the preparation of this manuscript.

\section{References}

1 Park, R.C. and Crawford, M.H. Heart of the athlete Curr Probl Cardiol 1985, 10, 3-73
2 Jackson, A.S. and Pollock, M.L. Generalized equations for predicting body density of men $\mathrm{Br}$ J Nutr 1978, 40, 497-504

3 Feigenbaum, H. Echocardiographic measurements and normal values, Lea \& Febiger, Philadelphia, 1986

4 Devereaux, R.B., Casals, P.N., Kligfield, P. et al. Normalization of left ventricular anatomic measurements Clin Res 1983, 31, 178A

5 Vank, L. Somatometric investigaitons of top cyclists at the World Championships 1969 in Cycling and Health 1973. Proceedings of functional and somatometric examinations of top cyclists taking part in the World Championships, 1969, 185-203

6 Burke, E.R. Physiological characteristics of competitive cyclists Phys Sports Med 1980, 8, 79-84

7 Hermansen, L. Oxygen transport during exercise in human subjects Acta Physiol Scand 1973, 399 (suppl), 1-104

8 Saltin, B. and Astrand, P.O. Maximal oxygen uptake in athletes J Appl Physiol 1967, 23, 353-358

9 Gilbert, C.A., Felner, J.M., Heymsfield, S.V., Nutter, D.O., Perkins, J.V. and Schlant, R.C. Echocardiographic study of cardiac dimensions and function in the endurance-trained athlete. Am J Cardiol 1977, 40, 528-533

10 Raskoff, W.J., Cohn, K. and Goldman, S. The athletic heart, prevalence and physiological significance of left ventricular enlargement in distance runners JAMA 1976, 236, 158-162

\section{BASM Education Programme}

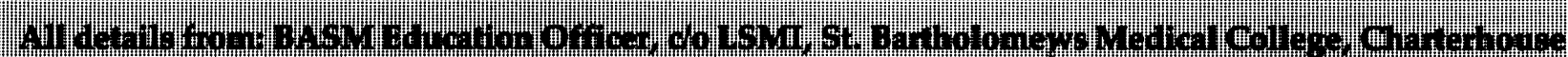

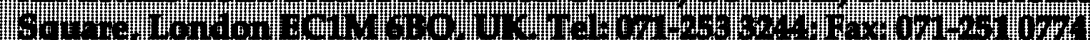

Date

Course

Venue

1991

March 1-3

Advanced Medicine of Physical Exercise \& Sport

LSMI

April 12-14

Advanced Physiology Module: Cardiorespiratory System

BOMC,

Harrow

April 21-26

BASM Introductory Sports Medicine Course

Lilleshall

May 17-19

Advanced Injury Module: Upper Limb

Crystal Palace NSC

June 14-16

Advanced Injury Module: Chronic and Overuse Injuries

Hillingdon

Hospital

September 29-October 4

BASM Introductory Sports Medicine Course

Lilleshall

November 8-10

BASM 1991 Annual Congress, sponsored by Lederle Laboratories. Details from: John Clegg, Birch Lea, 67 Springfield Lane, Eccleston, St. Helens, Merseyside, WA10 5HB, UK. Tel: (0744) 28198

Lowwood

Hotel,

Windermere,

Cumbria

November 22-24

Advanced Physiology Module

BOMC,

Harrow 